\title{
The youngest ctenocystoids from the Upper Ordovician of the United Kingdom and the evolution of the bilateral body plan in echinoderms
}

Imran A. Rahman, Sarah E. Stewart, and Samuel Zamora

Acta Palaeontologica Polonica 60 (1), 2015: 39-48 doi:http://dx.doi.org/10.4202/app.00048.2013

During the early Palaeozoic, echinoderm body plans were much more diverse than they are today, displaying four distinct types of symmetry. This included the bilateral ctenocystoids, which were long thought to be restricted to the Cambrian. Here, we describe a new species of ctenocystoid from the Upper Ordovician of Scotland (Conollia sporranoides sp. nov.). This allows us to revise the genus Conollia, which was previously based on a single poorly-known species from the Upper Ordovician of Wales (Conollia staffordi). Both these species are characterized by a unique morphology consisting of an elongate-ovoid body covered in spines, which clearly distinguishes them from their better-known Cambrian relatives; they are interpreted as infaunal or semi-infaunal burrowers from deep-water environments. This indicates that the ctenocystoid body plan was not fixed early in the evolution of the group, and they most likely modified their structure as an adaptation to a new mode of life in the Ordovician.

Key words: Echinodermata, Ctenocystoidea, evolution, bilateral symmetry, body plans, Ordovician, United Kingdom.

Imran A. Rahman [imran.rahman@bristol.ac.uk], School of Earth Sciences, University of Bristol, Wills Memorial Building, Queen's Road, Bristol BS8 1RJ, UK; Sarah E. Stewart [sarah.stewart@nms.ac.uk], Department of Natural Sciences, National Museum of Scotland, Chambers Street, Edinburgh EH1 1JF, UK; Samuel Zamora [samuel@ unizar.es], Department of Paleobiology, National Museum of Natural History, Smithsonian Institution, Washington DC, 20013-7012, USA; and Museo Geominero, Instituto Geológico y Minero de España, C/ Manuel Lasala, $44-9^{\circ}$ B, 50006 Zaragoza, Spain.

This is an open-access article distributed under the terms of the Creative Commons Attribution License (for details please see creativecommons.org), which permits unrestricted use, distribution, and reproduction in any medium, provided the original author and source are credited. 
POFig Full text $(1,044.3 \mathrm{kB})$

Forg Supplementary file $(16.9 \mathrm{kB})$ 